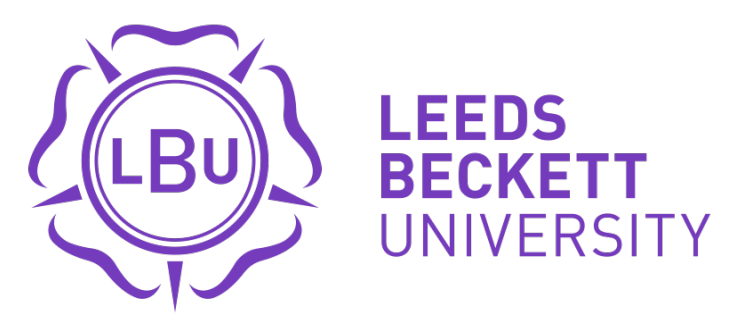

Citation:

van Ingen, C and Sharpe, E and Lashua, BD (2016) Neighborhood stigma and the sporting lives of young people in public housing. International Review for the Sociology of Sport. ISSN 1461-7218 DOI: https://doi.org/10.1177/1012690216641146

Link to Leeds Beckett Repository record:

https://eprints.leedsbeckett.ac.uk/id/eprint/2575/

Document Version:

Article (Accepted Version)

The aim of the Leeds Beckett Repository is to provide open access to our research, as required by funder policies and permitted by publishers and copyright law.

The Leeds Beckett repository holds a wide range of publications, each of which has been checked for copyright and the relevant embargo period has been applied by the Research Services team.

We operate on a standard take-down policy. If you are the author or publisher of an output and you would like it removed from the repository, please contact us and we will investigate on a case-by-case basis.

Each thesis in the repository has been cleared where necessary by the author for third party copyright. If you would like a thesis to be removed from the repository or believe there is an issue with copyright, please contact us on openaccess@leedsbeckett.ac.uk and we will investigate on a case-by-case basis. 


\section{Neighborhood stigma and the sporting lives of young people in public housing}

\section{Introduction}

Scholarly work continues to argue that communities matter a great deal and that our lives are powerfully shaped by where we will live (Kelaher et al, 2009; Sampson, 2012; Wacquant, 2007, 2008). Yet, poor neighborhoods often acquire notorious reputations (Kelaher et al, 2009). The residents of such places, Wacquant (2007) argues, are often marked not only by the stigma of race and class, but also by a "blemish of place" that, much like many other forms of stigma, "reduces them from a whole and usual person to a tainted, discounted one" (Goffman, 1963: 3). Our research is interested in young people's 'neighborhood narratives,' and the way that they experience, manage and resist spatial stigma while living in a neighborhood identified as 'disadvantaged'. In addition, we are interested in how, and where, sport figures into young people's sociospatial identities. The term 'sport' is used here in its widest sense to cover many aspects of physical activity, "including physical education and school sport, leisure/communitybased participation and competitive sport at elite level" (Benn, Pfister, and Jawad, 2011: 1).

Over the last year our research team began a multi-year ethnographic project working with young people from public housing neighborhoods in the Niagara region of Canada. These neighbourhoods received 'priority neighbourhood' designations, whereby public and private funds are used to improve services for residents. Despite this funding, there is a long waiting list to get into public housing with priority being given to people who are victims of violence, homeless, or facing health and safety issues. In 2014, only 
$20 \%$ of those on the waiting list for public housing were placed, and the average wait for a two or three bedroom unit was 2.5 years (Niagara Regional Housing, 2014).

'Redcrest' is one of these priority neighbourhoods and contains 110 housing units subsidized through the rent-geared-to-income (RGI) system managed by the Niagara Regional Housing Authority, the metropolitan arm of the Ontario Housing Corporation. Rent is calculated at $30 \%$ of the gross monthly income for the household up to the maximum market rent amount. Niagara residents have borne the heavy weight of economic restructuring, particularly the loss of unionized manufacturing jobs and the growth of low-wage, causalized service. For the vast majority of existing tenants in Redcrest, for whom household income is very low and poverty the norm, buying regular ownership units or moving into low-end, 'affordable' housing markets is not an option.

Redcrest exhibits the characteristics of spatially concentrated racialized poverty (Silver, 2011). Most young residents belong to low-income, underemployed, or welfaredependent families, a significant portion of whom were led by single women. While the vast majority of residents in Niagara are white, the majority of Redcrest residents are of Arabic/African descent, primarily Sudanese, Libyan, and Kurdish. As one of our youth participants explains, "There is a lot of Sudanese people. There used to be a lot of Somalian people...Just people from different countries and not really a lot of white people." In addition, many Redcrest residents are Muslim, which stands in stark contrast to the present white settler colonialism that is an ongoing reality in the Niagara region.

This paper provides insight into how young people living in Redcrest experience neighborhood stigma, high levels of racialized poverty, racism, and Islamophobia, and how this impacts their sporting lives. In this context, we suggest that the neighborhood 
stigma experienced by young people is not adequately explained by 'the neighborhood effect" and its spatial logic as outlined in the work of Robert Sampson (2012). Rather, in this paper, we built on Henri Lefebvre's understanding of the urban, in particular, territorial relationships between central and peripheral spaces and Loic Wacquant's writings on neighborhood stigma. We suggest that neighbourhood-level approaches such as "eco-metrics" (Sampson 2012) need further infusion from spatial theorists and postcolonial scholars like Frantz Fanon, who further understandings of racism as a spatial relation and modality of colonialism (Kipfer, 2005; Kipfer \& Petrunia, 2009).

\section{Neighbourhood Effects}

As van Ham and Manley (2012: 2) outline, "over the last 25 years a vast body of literature has been published on neighbourhood effects: the idea that living in more deprived neighbourhoods has a negative effect on residents' life chances over and above the effect of their individual characteristics". van Ham and Manley also acknowledged that the volume of work was still growing. In 2012, when they published Neighbourhood Effects Research at a Crossroads, Google Scholar returned more than 17,000 hits on "neighbourhood effects". At the time of this writing, the same Google Scholar search yields 404,000 results. At the centre of contemporary research on neighbourhood effects is Robert Sampson, an urban sociologist at Harvard University.

Sampson's (2012) book, Great American City: Chicago and the Enduring Neighborhood Effect, demonstrates the powerfully enduring impact of place. Based on a large-scale research project, the "Project on Human Development in Chicago Neighborhoods", data was collected from 1994 to 2002, producing volumes of data "that other quantitative sociologies must lust after" (Orum, 2014: 505). The study involved a 
longitudinal cohort of over 6,000 children and their families who were tracked wherever they moved in the U.S over 7 years. In particular, the project examined the causes and pathways of juvenile delinquency, adult crime, substance abuse, and violence (Sampson, 2012). The study was methodologically innovative and observed public spaces by mounting cameras in the backseat of SUVs and filming each side of the street while driving slowly, in effect employing the early version of Google Street View. These films were used to code detailed aspects of the physical and social structure of these neighborhoods (Sampson, 2012).

Sampson's overarching thesis rejects that globalization and technology have rendered our lives 'placeless'. Rather he argues, that differentiation by neighborhood is pervasive and enduring — with cultural and social mechanisms of reproduction — and with effects that span a wide variety of behaviors. Whether it be crime, poverty, child health, protest, leadership networks, civic engagement, home foreclosures, teen births, altruism, residential sorting, collective efficacy, or immigration diffusion, the city is ordered by a spatial logic ("placed") and yields differences as much today as a century ago (Sampson, 2012b).

Sampson asserts that to understand neighborhood inequality you have to study the neighborhood itself and the location of the neighborhood in the larger context. To obtain more objective measures, his project developed new methods and statistical analyses to assess neighborhood characteristics, using a new analytic framework called "ecometrics". Ecometrics moves beyond individual-centred questions and surveys, or "methodological individualism” which Sampson (2012) argues characterizes 
contemporary social science and public policy.

This is an exceptionally brief summary of an extensively researched, large, and in many cases, exemplary study, one that is frequently heralded as a central text for sociologists. As our own project is focused on neighbourhoods, we also read Sampson's work to be informed on the latest concepts and techniques to come out of neighbourhood effects research. However, our own understandings have been deeply inspired by the theoretical insights of Henri Lefebvre (1991, 2009), Loic Wacquant (2007, 2006), and the spatial dimensions in the work of Frantz Fanon $(2005,2008)$. These works detail how hegemonic power actively produces and reproduces difference as a key strategy to maintain modes of social and spatial division that are advantageous to its continued empowerment and authority (Kipfer, 2005; Lashua and Kelly, 2007; Van Ingen, 2003). Whereas Sampson deploys elaborate statistical analyses, which is valuable and insightful, he dismisses scholarship that has laid the foundations of work about cities, neighborhoods, race, and poverty ${ }^{1}$. Anthony Orum, also a leading Chicago researcher who has published significant work on the politics of race and urban space, reviewed Sampson's book. Orum writes that the text was so widely applauded by "virtually every leading sociologist in America" that "frankly, I was leery of writing a review of it for fear of finding myself on the outside of the sociological establishment" (2014: 505). Echoing Orum, we too believe the text failed to acknowledge theoretical, narrative, and descriptive data outlining racism as a spatial relation. Moreover, taking up the stance of "radical contextualism" (Grossberg, 2010), we are interested in how power infiltrates, limits, and empowers the possibilities that young people have to live their lives in Redcrest. We do this work by engaging ethnography as a mode of empirical inquiry, an 
approach that has been a staple of work in urban scholarship, though dismissed in the writings of Sampson (Orum, 2014).

\section{Methodology}

As part of a larger 3-year study, this paper reports on data collected over eight months with 14 young people between the ages of 13 and 22 years old in Redcrest. To recruit participants, we connected with a teen program operated by a non-profit youth organization funded through a 'neighborhood investment' program. After receiving ethical clearance from the University and with support from the regional housing authority, and the organization running the teen program, we advertised and held introductory meetings in a community space within Redcrest. These neighborhood meetings gave young people the chance to hear about the research, enjoy some food, and ask questions, as well as provided us opportunities to speak with parents/guardians. At these meetings we invited young residents to take part in our project through interviews, a neighborhood mapping exercise, and youth-guided walking tours around local sport and leisure sites. Participants were given an honorarium and pseudonyms were used to protect their identity.

In the interviews participants were asked to tell us about Redcrest, and to draw a neighbourhood map while they were narrating their stories of living and growing up there. This process, when applied to discussions about the conditions of specific localities, has been called “community mapping." For Amsden and VanWynsberghe (2005: 357) community mapping is "a visual and relational data-gathering technique that can be used to document not just geographical, but also other forms of abstract data" which for us includes illustrating spatial relations such as social class and racialized 
identity construction. This style of interview draws upon the hand-drawn 'cognitive mapping' approach of Lynch (1960), who interviewed shoppers and asked them to sketch maps of their everyday routes within a city centre. Hand-drawn, or "sketch maps" are useful toward developing in-depth understandings of group and individual spatial narratives (Boschmann and Cubbon, 2014). As Turchi (2004: 11) put it: "to ask for a map is to say "tell me a story."” This active, open process allowed young people to provide mappings of Redcrest, both verbally as stories about who they are, and as maps on paper about their neighbourhood sport and leisure spaces.

To build upon the sketch maps made during interviews, young people were invited then to take us on walking tours (Carpiano, 2009; Emmel, 2008; Evans and Jones, 2011; Hall, Coffey, and Lashua, 2009) or ethnographic 'go-alongs' (Kusenbach, 2003) to show us around 'their' Redcrest: the spaces where they hang out, play sport, and engaged with others in the locality. In these walking and talking tours, our movement through the neighbourhood served as a prompt for further discussion about it. That is, walking tours alert us to the mundane and 'everyday' spaces that figure in young people's lives, which may not have been thought of as important during the initial interview or on the sketch maps (Hall, Coffey and Lashua, 2009). Our research assistants, Tyler and Katie, spent many afternoons and evenings collecting data in the neighborhood, spending time interviewing, and moving between fast food joints, the basketball courts, and especially hanging out at the neighborhood teen program. Like Landolt (2013: 628) we agree "that 'hanging out' in neighbourhoods is about far more than micro-scale youth geographies and that the neighbourhood is also an important 
resource" in the construction and reconstruction of young people's sense of identity and community (Fink, 2012).

We relied heavily on Tyler, a first year graduate student of Caribbean descent, and Katie, a white senior undergraduate student, for fieldwork and data collection. Both in their early 20s, they joined our team as novice researchers and received training on interviewing, community mapping, and go-along interviews. As this project adopted creative approaches to research interviewing, our research assistants kept research journals and attended bi-weekly meetings where the research team often discussed, among other things, the 'researcher' and 'friend' aspects of fieldwork roles. In particular, the research team reflected on the ways in which the researcher both influences and is influenced by the research, and the ways in which the identities of the researchers influence the nature and structure of the research relationship.

In addition to ethnographic fieldwork, data collection included neighborhoodcentric documents that provided information on the residential area and local public housing initiatives. These documents included, for example, census data, municipal data, planning council reports, and local media coverage. We then engaged in thematic and theoretical analysis to identify patterns of meanings across these datasets.

\section{Redcrest: A site of crisis or community?}

Public housing projects are often stigmatized as bad places to live, as havens of poverty, illegal activity and violence (Silver, 2011). Jim Silver, who has written extensively on poverty and public housing in Canada, argues

Public housing and its residents are stigmatized and stereotyped in ways that obscure more than they reveal and that feed into a long-standing theme in the 
study of urban poverty that places the blame for their often-difficult circumstances on public housing residents themselves, identifying their behavior and their cultural attributes as the primary sources of their poverty (2011: 10).

Indeed, structural inequalities intimately connected to colonialism, racial and gender discrimination, and neoliberal government policies are not held accountable for creating conditions that make a growing number of people vulnerable to poverty and its effects (Silver, 2014). Rather individuals and their neighborhoods are blamed.

Take, for example the following newspaper articles that render Redcrest tenants as social 'outcasts' living in what Wacquant (1996) refers to as "neighborhoods of exile" where only the jobless and social assistant recipients live. One article focuses on a local "church that is active in helping the needy" - the "needy" were identified as residents of Redcrest ${ }^{2}$. Newspaper searches involving Redcrest often reported on young offenders, drugs, weapons, home invasions, sexual assault, and theft charges. The powerful stigma attached to public housing projects and its residents is clearly reflected in the following newspaper article, for that reason we quote from the article at length:

"Everyone is out on their patios on this July afternoon, smoking an endless chain of cigarettes in shorts and sleeveless T-shirts, leaning over black laquered fences to chat with the steady flow passing by. They all know each other at [Redcrest]."

"It's the kind of story that shocks a community. When it happens at [Redcrest], a subsidized housing complex in [city], it's the kind of story that reinforces a lingering perception and undermines continual efforts to shed the neighborhood's bad image." 
"But when it's summertime in a low-income neighborhood where many residents are home all day and a high-profile incident pits neighbor against neighbor, the problems inevitably fester under the hot sun."

"[One resident], who's lived 12 years at [Redcrest], says with the equivalent of four city blocks crammed into such a compact area -- people from around the world, living all kinds of lives -- it's amazing there isn't more trouble."

"They've already suffered through a lot living here," says housing advocate [name removed]. "Personally, I don't want to see them suffer any more."

The powerful stigmatization of Redcrest as a site of depravity is a central feature of the article (i.e., everyone is chain-smoking in sleeveless T-shirts, residents have all suffered through living in Redcrest, and, it is implied, are jobless, and therefore home all day). How the media portray particular neighborhoods can have real consequences, producing hegemonic discourses that stigmatize residents of public housing. Moreover, neighborhood stigma can have a significant impact on children and young people who are often more physically bounded to their home and neighborhood than adults are (Purdy 2003).

We draw here on interviews with youth residents who disclose their racialized experiences of sociospatial marginalization. In other words, they discuss the ways Redcrest is produced as a marginalized and racialized space and how they experience, and, in some ways challenge, processes of exclusion._In each interview young people were asked the following question, "If a friend wanted to come to visit that hadn't been to Redcrest before, how would you describe the community to them?" Laela replied, "One word: ghetto." When asked to elaborate on her answer she continued, "Because 
most of my friends ... their parents have good jobs and they have nice houses and they live in a nice community. If they came to Redcrest it would be really different to them. I don't know how they would think of it - like in their mind they'd probably think what is this? But they wouldn't say that, obviously."

What Laela is describing as "ghetto" and "really different" is what Wacquant (2007, 2008) refers to as 'territorial stigmatization'. Territorial stigmatization is when specific neighbourhoods, like Redcrest, face heightened disparagement (often explicitly coded in racial terms) that is also traced on to the bodies of its residents. This stigmatization weighed heavily on young people's sense of their neighborhood. Fareeq, a sixteen year old in grade 11 explains,

Redcrest, it just has a bad reputation, a really ghetto kind of place. The best way to describe it ... when me and my brother are at school, we're looked at like, just like black people, we live in Redcrest. Most of our friends that have come they're surprised because all the stuff that they have in their head about this place is really negative. And they'd come and it's not as bad as they thought, it's just like a regular neighbourhood.

Indeed, the term 'ghetto' was overwhelming used as a descriptor of Redcrest, with young residents well aware of the negative status infused in the term. Their words echoed those of Wacquant (2008: 170) who argues "public housing is invested symbolically with racialized images of social pathology".

Indeed, racialization and racism are intrinsic to the stigmatization of public housing (Kipfer \& Petrunia, 2009; Waqucant, 2008). Yet, as Lefebvre (1991) argues, different types of space interact, overlap, allowing parallel and conflicting reputations to coexist 
(Van Ingen, 2004). Similarly, David Goldberg (1993) argues that while racialized spaces, such as Redcrest, are often considered bleak and degenerate spaces, they can also be liberating and open. Fareeq, who shared his experience of neighborhood stigma, explains how much he loves Redcrest, "In this community, to be honest it's great because everyone literally knows you. If you walk around pretty much like this whole neighbourhood is pretty much Sudanese. So you pretty much know all the parents and stuff”. Mena, a 15 year old girl with Libyan parents echoes this sentiment, declaring, when you say Redcrest they usually think ghetto...it's not fair to generalize all Redcrest kids but when somebody asks 'where do you live?' I don't usually say Redcrest. I say a nearby street or something, because you don't want people thinking that you live in a ghetto or bad area. But at the same time I love Redcrest. I wouldn't want to move, even though Redcrest is not considered one of the nice places, I wouldn't want to move.

Randa, who is in her early 20s, moved to Canada from Sudan when she was 13, explains that, There's a lot of Sudanese people so I don't feel out of place. They're always in your house, you're always in their house. They invite you to come eat dinner, have tea and biscuits or just have a visit, drop by and say hi. Since I started school there was complaining about how I don't stop by anymore. Other people too, like you make a connection with them. It's not just the Sudanese people, it's the whole community.

Randa's response is echoed in Jim Silver's (2011) findings on the experience of residents in Canadian public housing projects in Vancouver, Winnipeg, Toronto, and 
Halifax. He explains, "contrary to popular opinion and contrary to the stigma and stereotypes that fuel that opinion - inner-city public housing projects can be good places to live (p. 12). Randa highlights the support that she and other Sudanese residents derive from informal social networks within Redcrest. It is also important to outline that the Sudanese population in Niagara is diverse and their migration and settlement experiences are more complex than is being addressed here. Moreover, there are ethnic (Arab and African), linguistic (Arabic, English, Arabi Juba, as examples) differences, and two major denominations of Islam (Shia and Sunni) practiced amongst the Sudanese residents ${ }^{3}$.

\section{Sporting Lives: Neighbourhood informal sport and leisure spaces}

It is well documented that participation in organized sport is highest for children in high-income families and lowest among children from lower income households (Clark, 2008). Very few young people in our study were participating in organized sport. Of the 14 participants (4 males and 10 females), only three males were playing organized, competitive sport. In addition to financial obstacles (equipment, registration fees, transportation, etc.) and family commitments (caring for younger siblings), there were additional gendered restrictions limiting girls' mobility and opportunity to engage in formal and informal sport and physical activity in comparison to male peers (Clark, 2015). Kelifa, who moved to Canada as a young teen, explains:

Back home [in the Sudan] you can't play sports. My mom didn't like it, she didn't

like the idea of a girl playing sports and going to the gym and working out and all that stuff. But if I want something, I do it regardless. She didn't like the idea but she got used to it. I'm stubborn like my dad. Now she is used to it. They're strict. My dad has 
been here [in Canada] long enough but when we first started my mom, was like 'what is this', 'what is that'? 'You can't do this, you're a girl'; 'No you can't do this'. I'm like, mom, it's okay!

In addition to Messner \& Musto's (2014) call to devote more scholarly attention to both children/youth and children/youth sport, Canadian sport scholars, with few exceptions, have not written in-depth on Muslim girls experiences in sport (Jiwani and Rail, 2010; Nakamura, 2002). As Jiwani and Rail (2014) note, young Muslim Canadian women interested in physical activity or sport seem to confront multifaceted problems beyond the ethnocentrism of sport scholars, including concerns over religious headgear, and stereotypes as passive and oppressed girls. Similarly, Stride (2014), writing on South Asian, Muslim girls experience in school-based physical education in England explains, "Muslim girls face more challenges than Muslim boys in the context of physical activity" (p. 251). Indeed, there is still much more work that needs to be done to determine meaning and value of physical activity and sport in the diverse lives of young girls who negotiate religious and cultural orthodoxies as well as Western patriarchal culture.

(Ratna, 2010; Stride, 2014).

\section{Unveiling}

As Benn, Pfister, and Jawad, (2011), and others have outlined, Islamophobia and stereotypes of Muslim people as dangerous and radicalized has accelerated in the West following the terrorist attacks of September 11, 2001, and through other incidents, including the more recent attacks on November 13, 2015 in Paris. The public divide between Islam and the West is reflected in the headscarf debate, a debate that ferments a moral panic about Islam and racism in Canada and elsewhere. Most recently in Canada, a 
government regulation (which was subsequently overturned) to prevent Muslim women from covering their faces by wearing the niqab during their citizenship ceremonies was manufactured into an electoral issue. The country's Conservative anti-Muslim turn was most certainly felt by the young residents of Redcrest, who have continually had to assert their own identity in a racist environment.

While much has been written in mainstream media about hijab-wearing women and sport, "in-depth knowledge of this topic is inexistent as very few sport scholars have endeavored to research this issue" (Jiwani and Rail, 2010: 251). We acknowledge the importance of filling the gaps in the literature, and for understanding Muslim women's sport experiences. We also acknowledge that our interviews did not explicitly ask young women to discuss their religious observance unless they drew the mosque in their community map, or discussed religion in the interview. Rather participants were asked to describe and talk about their neighborhood and about their reasons for partaking (or not) in sport. Participants who identified the mosque as an important community site, who talked about Islamic religion, or the hijab, were asked to elaborate on these. However, we did not ask about their views of sport in relation to Islam and the hijab. Such an approach is what distinguishes Jiwani and Rail's (2010) article on young Shai Muslim Canadian women's discursive constructions of physical activity and Yuka Nakamura's (2002) project on the physical activity experience of Muslim women who were born in or immigrated to Canada.

In our project, several participants removed their hijab for undeniably complex reasons, not all of which were covered in our interviews. Some continued to wear the hijab whether as an expression of religious conviction, parental coercion, or any other 
reasons. In their academic lives, many young people in Redcrest attend Catholic, rather than public schools. Parents often felt that Catholic schools provided a better education, and preferred a school with religious orientations to secular ones. In speaking to her school experience, Saba, who is now 19 years old, explained that she started wearing the hijab in grade 9, while attending Catholic school.

I used to wear the scarf around my head. A lot of people didn't talk to me. I don't know. Because I go to school and I really don't want to be there. I was just quiet because I was afraid of other people judging me because of the scarf on my head. ...I don't want to get into it because it's really touchy. But I liked [the Catholic school], it was a really good school. It's just that I think I missed out on a lot of things because I was always so worried about what other people thought about me. I didn't just swallow my anxiety and just go and do whatever because I was too afraid that people were judging me for what I had on my head rather than the things that I'm interested in.

Given that Saba expressed that she was uncomfortable sharing more about her experiences wearing the hijab, the interviewer did not follow up with specific questions. However, Saba did return, briefly, to the topic once more in the interview. She explained, “there were a few incidents where I've seen people making fun of it." She also explained that,

the only time people started talking to me that I never talked to was on [Grade 12] prom night, because I didn't have it on, and I guess they didn't see me as a threat anymore. Yeah, the reason I was shy is because I wore it and I had an anxiety of people judging me and the stereotypes and stuff like that, that's kind of 
what I was thinking about all the time. They probably weren't thinking that way but... Even now I still have anxiety from that, that's because if you ever notice that I'm not talking, like if anyone enters the room and I never talk to them it's that anxiety of they're going to judge me before they know me and stuff like that. But it's on my head but I can't ignore it, it just takes over.

Kelifa, another young Muslim women talked abut wearing the Hijab when she was younger and making the decision to no longer wear it. She explains, I used to wear a hijab but then I took it off because I didn't want to wear it anymore and my dad was forcing me to wear it. I was still praying and reading and stuff, but if I'm forced to do something I won't accept doing it.

When asked how old she was when she stopped wearing the hijab, Kelifa replied, "I was in grade 11 , so probably 15 or 16 ." She also notes, "My dad is still not happy about it. I don't speak to my dad unless I really have to. We don't really get along. But my mom got over it."

Saba and Kelifa expressed different relationships with the hijab, yet both acknowledged that, for varied reasons, it was a source of tension. In particular, Saba, who wore the hijab while attending Catholic high school felt anxious, afraid, and judged by her peers. She did not seek out or participate in any school-based sport, yet she did so in Redcrest. Saba clearly explained the stereotypes she faced at school. She also explained that it was different for Muslim boys since "you can't really identify that they're Muslim because they don't have anything that they are wearing to show that they are". While there is no single "female Muslim" experience, school is a site where girls faced different obstacles and continually navigated the complexity of their identities. 
Homi Bhabba (2008) explains in the introduction to Fanon's Black Skin, White Masks, that Fanon wrote about the colonizer's attempt to unveil the Algerian woman, explaining that that every veiled women became suspect. Acknowledging that a much different context impacts the Niagara-region, what is contextually relevant is the Islamophobia and gendered racism that informed Saba's experiences, leaving her feeling stereotyped, judged, viewed as a threat, and ignored by her classmates. Kelifa chose to no longer wear the hijab, something that remained a source of tension with her father. In both cases, we need to see context, different observances and obstacles, and the complexity of identities in order to be able to improve access to sports for Muslim girls and women.

We note that when Muslim girls and young women from Redcrest talked about various forms of physical activity, this was rarely in connection to organized, competitive sport. Absence from organized sport, however, did not mean that they were not interested in a wide range of physical cultural forms (including, but certainly not restricted to, sport). For the interview phase of this research, we invited young people to draw a map of their neighbourhood as they were telling their story of living and growing up in Redcrest. This process, when applied to discussions about the conditions of specific localities, has been called “community mapping” (Amsden and van Wynsberghe, 2005). The interview data and the maps drawn by participants showed that the there were four main locations for sport - the local Young Men's Christian Association (YMCA), the community basketball court located within in Redcrest, a nearby park, and through the neighborhood teen program.

The YMCA is a 30-minute walk from Redcrest, and is a place where many young 
residents go, particularly on Sundays to take swimming lessons, play basketball or workout. Time on Saturday, as many participants shared, is set often aside for Arabic school, so most of the trips to the YMCA happened on Sundays. The outdoor community basketball court was a significant site for sport, a place that Ibrahim explains "brings the community together, the little kids, and people my age or older". He, and many others, explained that the court, which is fenced in on all sides, is used "for things such as basketball, hockey, or soccer". The nearby park provides a space for young people to hang out, play soccer, or games like Manhunt. However, as thirteen year old Aliya explains, "the girls my age, ...they're not that active actually. Like if I say, 'oh, do you want to go to the park?' They'll probably say, 'yeah sure' and when we go they'll probably just stand there and talk." Aliya then clarified that outside of her school's physical education classes, the only other sport she engages in is through the neighborhood's teen program. In the after school program, Aliya joins her Redcrest friends:

And we do a lot of sports and stuff there ...like on Mondays we do yoga and then we do art. And on Tuesdays we go to the gym at [a school] and we just do whatever we want, like chill out, or play sports and stuff... play volleyball or tag or something like that.

It is the teen program that provides the most opportunities for active physicality for Muslim girls in Redcrest, and we turn our attention to that for the remainder of the paper.

\section{Neighborhood Teen Program}

The neighborhood teen program is a key location in the sporting lives of young people living in Redcrest. The regional housing authority partners with a range of 
organizations to provide supports and services within its communities. According to the housing authority, these programs are to help "mitigate the effects of poverty by building community spirit, offering lifeskills training and enhancing the lives of the tenants" (Niagara Regional Housing, 2013: 7). As a "priority neighborhood" in the Niagara Region, funding is provided to community agencies to develop programs and initiatives that address the needs of residents (Sharpe, 2013). A non-profit youth organization provides resource support, shelter, and outreach services to high risk and homeless urban and rural youth. The youth organization also offers free after-school programming at Redcrest for children 12 years and under and a teen program for those older than 13 years. Youth leaders, many former participants themselves, come to the site from 5-8 pm and offer a variety of activities. Programming includes access to snacks, meals, computers and homework help, drama, movie nights, field trips, and physical activity programming. The young people in Redcrest, particularly young girls, spoke of the teen program as an important social space in their lives.

Young males such as Ibrahim explained that the teen program "does have a strong meaning for me, I mean I go there and it's a pretty chill time, its relaxed, it's just a good place to be to be honest." However, young females identified the teen program as a space that enabled and enriched their sporting lives. Randa explains, the [teen] program ...offers us a lot of opportunities. Like I first tried horseback riding through the program and I don't think I would ever try that if I was not in that program. I went to my first concert with that program, and I don't think I'd ever go to a concert.

Similarly, Mena, who was born in Canada to Libyan parents, explains that she has been 
going to the youth programing "ever since I can remember". She explains that she is not motivated or interested in playing on school sport teams but loved to play sport in her own community. Mena played basketball on the community court, soccer in various yards and small open spaces in Redcrest, and attended the teen program most nights, including when the group went to a local school gym where she played basketball or other games. However, it is important to further contextualize her comments in order to trace out her disengagement in sport outside of her community.

In her interview, as well as in her sketch map of her neighborhood, Mena outlined that she had "home friends, my friends, and then I have my school friends that I see 5 days a week because of school." The interviewer asked if her friend groups ever 'mixed', or got together, to which she responded, "I don't like introducing them." She restated again that she did not want to bring her school friends to Redcrest. She explained, "I feel like at school you're more professional and at home... it's more comfortable, it's like they are family. They are basically family." She also described that her

school is in a really nice area. The houses are big. I think it's generally like older people that live in the houses and it's really nice and everything is well kept. So it's nice to go around the blocks during lunch or walking home.

A short while later the interviewer asked about Mena's experiences at school, she replied,

When I first went [to school] I realized it's not very diverse. That's another thing, if I were to bring my school friends with the Redcrest friends, I wouldn't ... because my Redcrest friends are all Muslim, that's one thing that we have in 
common. All my school friends are white people. I just don't like that about

[school]... it's not diverse. Literally, 95\% white people. So that is what I notice.

Yeah, it's just hard being the minority.

In returning to a discussion on sport, Mena explains, "I've tried to get involved in school activities and sports but it's like I don't want to do it by myself'.

Fanon's analysis of everyday racism as an alienating spatial relation is key to understanding Mena's experiences in different spaces, and how this impacts her sporting life. Mena's experiences can be read through Fanon's (2005) description, in his classic text, The Wretched of the Earth, of the compartmentalized structure of colonial society. Fanon speaks to the ongoing legacies of colonialism, and in particular, the relationship between the center and the periphery. He explains, "if we examine closely this system of compartments, we will at least be able to reveal the lines of force it implies" (2005: 3738). Indeed, Fanon's writings inform contemporary discussions on marginalized spaces within cities, providing a tool for interpreting power relations. Likewise, Lefebvre states, "space and the politics of space "express' social relationships but react against them" (2003: 15). As Kipfer and Petrunia (2009) argue, Lefebvre's analysis and writings on the city and territorial relations between centres and peripheries needs to be stretched and infused with approaches that are explicitly anti-racist and, we would argue, feminist.

Lefebvre paid attention to everyday life as a contradictory experience, and examined the ways in which the state plays a key role in exercising social control by organizing people into "a hierarchy of spatially demarcated spaces" (Kipfer and Petrunia, 2009: 113). Similarly, Fanon, in Black Skin, White Masks, insisted that racism be understood as an "everyday", "visible", and "systematized hierarchisation" (Kipfer, 
2007). According to Fanon, the everyday experience of racialization, of being "walled in" through others gestures, body language, and looks caused some black people to try to assimilate into "normalcy" (2008: 89). In her mostly white school, Mena, when asked by her schoolmates where she lives, hopes to leave the stigma of Redcrest behind by claiming to have a home elsewhere. This is the banality of racism that Mena and others encounter in their everyday lives. How she experiences her body as 'matter out of place' (Hall, 1997) at school stands in juxtaposition to the sociospatial compartmentalization of her home life. Mena has few opportunities and supports to engage in school sport or activities because of this compartmentalization. She has such support and a sense of belonging in the Redcrest teen program, which is an adult-supervised, programmed space, and a place where she happily and comfortably engages in sport. Fanon's texts suggest that racism must be understood spatially (in historical) and contemporary terms.

\section{Conclusion}

The focus of this paper was to examine the neighborhood narratives of young people in Redcrest, to highlight the ways in which they experienced, managed and resisted spatial stigma while living in a neighborhood identified as disadvantaged. After a brief examination of Sampson's (2012) neighborhood effects approach, we drew from the theoretical insights of Lefebvre, Wacquant, and Fanon, to examine neighborhood stigma and racism as a spatial relation as well as the sporting lives of young people living in Redcrest.

Redcrest is a stigmatized place. The young people in our study articulated the grinding experience of neighborhood stigma, which often renders "unfamiliar places apprehensible (knowable) to outsiders, by making outsiders apprehensive of them" 
(Klocker, 2015: 422, emphasis in original). Indeed, spatial racial boundaries were experienced in a myriad of ways. Youth residents reported belonging and social exclusion, feeling in and out of place, in certain neighborhoods, school and sport settings. We reflect on the impact of the prevalent stereotypes of Redcrest and its residents, as well as other neighborhoods that are similarly stigmatized. While Lefebvre $(2014,2002,1991)$ has examined the deep roots and histories of peripheral spaces in cities, Wacquant's work on territorial stigmatization and urban inequity significantly informs our understanding of urban marginality. However, it is Fanon's way of linking an understanding of everyday racism as a fundamentally spatial process that provides "a useful source to elaborate a theory of 'place and identity' in postcolonial times" (Kipfer 2007: 707).

We indicated at the beginning of this paper that this research is part of a larger, multi-year project. As our research moves forward, we will continue to examine the profound impact and bodily experiences of neighborhood stigma in the lives of young people who live in public housing. This research will unfold through the words, stories and images of young people that are engaging in a youth-lead, digital storytelling project. Digital storytelling provides another means for young residents to talk about the context of their own lives and interpret, reflect, and artfully re-engage their world (Sawhney, 2009). Our desire is that this research informs and transforms responses to issues of social and spatial marginalization in the sporting lives of young people in public housing in Niagara. We aim to create a space, through the next phase of the project, for young people to talk back against the stigmatizing representations of their neighborhood that, as outlined in this work, has broader impacts. 


\section{Funding}

This work was supported by the Social Sciences and Humanities Research Council.

\section{Notes}

1 Orum (2014) argues that Sampson dismisses research that has been a staple of urban scholarship, such as Herbert Gans, William Foote Whyte, and many others.

2 The reference for the newspaper articles is withheld, to comply with research ethics protocols and not reveal identifying details about the particular public housing community we conducted research in.

3 The Study of Sudanese Settlement in Ontario - Final Report (2001) is a survey of Sudanese immigrants in Ontario, including the Niagara region, indicated that they are underemployed or economically excluded (without work), “experiences they find humiliating. Underemployment and unemployment do not depend on respondents' levels of education but occur in all educational categories" (p.18). 


\section{References}

Amsden J and Van Wynsberghe R (2005) Community mapping as a research tool with youth. Action Research 3(4): 357-381.

Benn T, Pfister G, and Jawad, H (2011) Muslim Women and Sport. London: Routledge.

Boschmann, E.E. and Cubbon, E (2014) Sketch maps and qualitative GIS: using cartographies of individual spatial narratives in geographic research. The Professional Geographer 66(2): 236-248.

Carpiano, R. M (2009) Come take a walk with me: The "Go-Along" interview as a novel method for studying the implications of place for health and well-being. Health \& Place, 15(1): 263-272.

Clark S (2015) Running into trouble: Constructions of danger and risk in girls' access to outdoor space and physical activity. Sport, Education and Society 20(8): 10121028.

Emmel, N (2008) 'Participatory Mapping: An innovative sociological method', Real Life Methods toolkit \#03: Participatory Mapping, ESRC National Centre for Research Methods. Available at: http://eprints.ncrm.ac.uk/540/2/2008-07-toolkitparticipatory-map.pdf (accessed 30 January 2016).

Evans, J, and Jones, P (2011) The walking interview: Methodology, mobility and place. Applied Geography 31: 849-858.

Fanon F (2008) Black Skin - White Masks, Charles Lam Markmann, (trans.). New York: Grove.

Fanon F (2005) The Wretched of the Earth, Constance Farrington, (trans.). New York: Grove. 
Fink, J (2012) Walking the neighbourhood, seeing the small details of community life: Reflections from a photography walking tour. Critical Social Policy, 32(1): 3150.

Goffman G (1963) Stigma: Notes of the Management of Spoiled Identity. New York: Simon \& Schuster.

Goldberg DT (1993) Racist Culture: Philosophy and the Politics of Meaning. London: Blackwell.

Grossberg L (2010) Cultural Studies in the Future Tense. Durham: Duke University Press.

Hall T, Coffey A, and Lashua B (2009) Steps and stages: Rethinking transitions in youth and place. Journal of Youth Studies, 12(5): 547-561.

Heath L, Gordon M, and LeBailly R (1981) What newspapers tell us (and don't tell us) about rape. Newspaper Research Journal 2(1): 48-55.

Jiwani N and Rail G (2010) Islam, hijab and young Shia Muslim Canadian women's discursive constructions of physical activity. Sociology of Sport Journal 27(3): 251-267.

Kelaher M, Warr D, Feldman P, and Tacticos T (2010) Living in 'Birdsville': Exploring the impact of neighbourhood stigma on health. Health \& Place 16(2): 381-388.

Kipfer S (2007) Space and Fanon: Colonization, urbanization and liberation from the colonial to the global city. Environment and Planning D: Society and Space 25(4): pp. 701-726.

Kipfer S and Petreunia J (2009) Recolonization" and public housing: A Toronto case study. Studies in Political Economy 83(1): 111-139. 
Klocker N (2015) Place stigma as boundary-making from the outside in: The case of Cronulla. Australian Geographer 46(4): 421-427.

Kusenbach M (2003) Street phenomenology: The go-along as ethnographic research tool. Ethnography 4(3): 455-485.

Landolt S (2013) Co-productions of neighbourhood and social identity by young men living in an urban area with delinquent youth cliques. Journal of Youth Studies, 16(5): 628-645.

Lashua B and Kelly J (2008) Rhythms in the concrete: Re-imaginging relationships between space, race, and mediated urban youth cultures. Leisure/Loisir 32(2): 461-487.

Lefebvre H (2014) Dissolving city, planetary metamorphosis. Environment and Planning D: Society and Space 32(2): 203-205.

Lefebvre H (2003) The Urban Revolution. Minneapolis: University of Minnesota Press. Lefebvre H (1991) The Production of Space. London: Blackwell.

Lynch K (1960) The image of the city. Boston, MA: MIT Press.

Nakamura Y (2002) Beyond the hijab: Female Muslims and physical activity. Women in Sport \& Physical Activity Journal 11(2): 21-48.

Niagara Regional Housing (2014) NHR Report-Centralized Wait List-Increase in Wait Times. Available at: www.onpha.on.ca/onpha/CMDownload.aspx (accessed 10 September 2015).

Orum A (2014) Great American City. Sociological Forum 29(2): 504-507.

Ratna A (2010) Taking the Power Back! The Politics of British Asian Female Football Players. Young: Nordic Journal of Youth Research, 18(2): 117-132. 
Sampson R (2012) Great American City: Chicago and the Enduring Neighborhood Effect. Chicago: University of Chicago Press.

Sampson R (2012b) “Ask The Expert: Robert J. Sampson.” CASBS at Stanford University. Available at: http://www.casbs.org/ask-expert-robert-j-sampson. (accessed 1 October 2015).

Sawhney N (2009) Voices beyond walls: The role of digital storytelling for empowering marginalized youth in refugee camps. In: Proceedings of the $8^{\text {th }}$ International Conference on Interaction Design and Children: 302-305.

Sharpe E (2013) Targeted neighbourhood social policy: A critical analysis. Journal of Policy Research in Tourism, Leisure and Events 5(2): 158-171.

Silver J (2014) About Canada: Poverty. Nova Scotia: Fernwood.

Silver J (2011) Good Places to Live: Poverty and Public Housing in Canada. Nova Scotia: Fernwood.

Stride A (2014) Let us yell you! South Asian, Muslim girls tell tales about physical education. Physical Education and Sport Pedagogy 19(4): 398-417.

Turchi P (2004) Maps of the imagination: The writer as cartographer. San Antonio: Trinity University Press.

Van Ham M and Manley D (2012) Neighbourhood effects research at a crossroads: Ten challenges for future research. Institute for the Study of Labor. University of Bristol. Discussion Paper No. 6793. IZA. [http://ftp.iza.org/dp6793.pdf].

Van Ingen C (2004) Therapeutic landscapes and the regulated body in the Toronto Front Runners. Sociology of Sport Journal 21(3): 253-269. 
Van Ingen C (2003) Geographies of gender, sexuality and race: Reframing the focus on space in sport sociology. International Review for the Sociology of Sport 38(2): 201-216.

Wacquant L (2007) Territorial stigmatization in the age of advanced marginality. Thesis Eleven, 91: 66-77.

Wacquant L (2008). Urban Outcasts: A Comparative Sociology of Advanced Marginality. Cambridge: Polity.

Wacquant L (1996) Red belt, black belt: Racial division, class inequality and the state in the French urban periphery and the American ghetto. In: Mingione E (ed) New Aspects of Marginality in Europe. Chichester: Wiley, 366-383.

Williams R (2004) The Politics of Public Housing: Black Women's Struggles Against Urban Inequality. New York: Oxford University Press. 